\title{
A Review on Suspended Wood Dust Combustion. Efficiency and Fuel Quality
}

\author{
Kaspars Silins, Riga Technical University, Institute of Energy Systems and Environment
}

\begin{abstract}
The paper is dedicated to review the combustion efficiency in low capacity wood dust suspension burners. Fuel quality is reviewed as the main contributor to the combustion efficiency. Wood dust moisture content, particle size and shape, amount of volatiles are discussed as the main contributors. Some additional aspects like burner ignition, fuel and combustion air feeding are reviewed to increase the efficiency.

A brief overview of particle combustion process is provided followed by an identification and discussion of combustion efficiency influencing parameters. The significance of fuel feeding and air supply is discussed at the end of the paper.
\end{abstract}

Keywords - moisture content, shape and size, swirl, volatile matter

\section{INTRODUCTION}

The EU has set high goals towards increasing the renewable energy share in gross final energy consumption (20\% in 2020 and at least $55 \%$ in 2050).

One of the options to increase the renewable share is cofiring fossil with biomass resources introducing wood dust in existing pulverized coal and natural gas fired systems. At present wood dust together with fossil fuels can be co-fired in up to $315 \mathrm{MW}$ scale power plants for greener energy production [1, 2, 3, 4]. Wood dust is used mostly for heat production, but can also be used in combination with Stirling engine for electricity production [5].

The future is combustion of $100 \%$ wood dust blends in the suspension burners - which is the scope of the paper. Wood dust combustion issues are discussed in this paper. The term wood dust - can refer to wood powder and fine sawdust (sizes up to $2 \mathrm{~mm}$ ). As specified in [6] wood fuel particle size of less than $1 \mathrm{~mm}$ is classified as wood powder and in between 1 $\mathrm{mm}$ and $5 \mathrm{~mm}$ - is classified as sawdust.

The aim of the paper is to review the combustion efficiency in low capacity wood dust suspension burners. It is necessary to understand the principle biomass combustion process in the suspension burners and the influence of the fuel quality towards the combustion process and its efficiency.

The first section of the paper reviews the principle biomass combustion process. When the combustion process is understood, the combustion efficiency determining factors are reviewed. In this regard, wood dust moisture content, particle size and shape as well as the amount of volatile matter are discussed as the main influencing factors. Some additional aspects like burner ignition, fuel and combustion air feeding are discussed regarding the increase of efficiency.

\section{Combustion of biomass}

The combustion within suspension burners is to be viewed on a single particle level. The combustion process of a wood particle can be divided into the following stages:

- Heating-up;

- Moisture evaporation;

- Devolatilization;

- Oxidation of volatiles and char.

Up to $100{ }^{\circ} \mathrm{C}$ the drying process takes place when the fuel particles are heated up and the moisture is evaporating. When the particle has dried, and the adequate temperature $\left(\sim 160{ }^{\circ} \mathrm{C}\right)$ had been reached, devolatilization of the volatile matter starts. The biomass particle releases gaseous compounds and a cracked char particle is left. Combustion of the volatiles starts at A temperature of $500{ }^{\circ} \mathrm{C}$. Complete combustion products are Carbon dioxide $\left(\mathrm{CO}_{2}\right)$, water $\left(\mathrm{H}_{2} \mathrm{O}\right)$, nitrogen and sulphur oxides $\left(\mathrm{no}_{\mathrm{x}}, \mathrm{SO}_{2}, \mathrm{SO}_{3}\right)$. Incomplete combustion products are unburned hydrocarbons (UHC- $\mathrm{C}_{\mathrm{x}} \mathrm{H}_{\mathrm{y}}$ ), Carbon monoxide (CO), carbon (C) and polynuclear aromatic hydrocarbons (PAH). After the full oxidation of volatiles, a glowing char particle is left. The char mostly consists of carbon which is being oxidized to $\mathrm{CO}$. When the $\mathrm{CO}$ reaches the char surface it is fully combusted to $\mathrm{CO}_{2}$ with a short blue flame. When the char has fully combusted, ash is left over consisting of minerals and metals. If the incomplete combustion takes place, the deposited ash still can contain an amount of unburned matter i.e. Carbon $[7,8,9]$.

\section{COMBUSTION EFFICIENCY}

The term combustion efficiency $\left(\eta_{c}\right)$ is used to determine the degree at which the wood dust has been oxidized. The methodology of CEN/TS 304 "Heating boilers - Test code for heating boilers for atomizing oil burners" and CENT/TS 303-5 "Heating boilers - Part 5: Heating boilers for solid fuels, hand and automatically stocked, nominal heat output of up to 300 kW - Terminology, requirements, testing and marking" standards state that the efficiency is calculated as a sum of four losses related to the heat input: heat losses with exiting flue gases, heat losses through the combustion system envelope, energy Losses through unburned matter in the ashes and chemically incomplete combustion products in flue gases. In the CEN/TS methodology, the total efficiency of the whole system is considered. In regard to combustion efficiency, the losses through the envelope and with the physical heat of flue gases are not being taken into account. For the suspension boilers there are two equations to calculate the combustion 
efficiency. For horizontal burners the combustion efficiency is calculated as (1)

$$
\eta_{c}=\frac{G_{u b c} * 33.9+V_{C O} * 283}{Q_{z}^{d}} * 100[5]
$$

where

$\mathrm{V}_{\text {co }}$ - amount of CO in the flue gases, $\mathrm{kmol} / \mathrm{kg}_{\text {fuel }}$

$\mathrm{Q}_{\mathrm{z}}{ }^{\mathrm{d}}$ - net calorific value of the fuel, $\mathrm{MJ} / \mathrm{kg}$

$\mathrm{G}_{\mathrm{ubc}}$ - unburned carbon content, $\mathrm{kg} / \mathrm{kg}_{\text {fuel }}$

The amount of unburned carbon can be determined by collecting the ash in the exiting flue gases with cyclones, filters or other particulate matter (PM) emission reduction equipment. Unburned carbon in the ash is determined as (2)

$$
G_{u b c}=\frac{C_{f a}}{A_{f u e l} * 100}[5]
$$

where

$\mathrm{C}_{\mathrm{fa}}-\mathrm{C}$ amount in the fly ash, $\%$

$\mathrm{A}_{\text {fuel }}-$ Ash content in the fuel, $\%$

The carbon amount in the fly ash is taken into account due to the assumption that all particles are being carried away with the exiting flue gases. The calculated combustion efficiency (2), represents the total unburned carbon loss of wood fuel, i.e. it is the lost heat due to incomplete combustion.

For Fluidized bed combustors, the equation used for combustion efficiency calculation is (3), taking into account two of the losses mentioned in [6].

$$
\eta_{c}=100-\left(\frac{32.866}{Q_{z}^{d}} *\left(\frac{C_{f a}}{100-C_{f a}}\right) * A+126.4 * V_{c o} * V_{d g} *\left(\frac{100-q_{u c}}{Q_{z}^{d}}\right)\right)[10],
$$

where

$\mathrm{q}_{\mathrm{uc}}$ - heat loss with unburned carbon, $\%$

$\mathrm{q}_{\mathrm{ic}}$-heat loss due to CO concentration, \%-vol,

The heat loss with unburned carbon therefore is calculated as (4)

$$
q_{u c}=\frac{32.866}{Q_{z}^{d}} *\left(\frac{C_{f a}}{100-C_{f a}}\right) * A[10],
$$

The loss due to chemically incomplete combustion $\left(\mathrm{q}_{\mathrm{ic}}\right)$ is calculated as (5)

$$
q_{i c}=126.4 * V_{c o} * V_{d g} *\left(\frac{100-q_{u c}}{Q_{z}^{d}}\right)[10],
$$

where

$\mathrm{V}_{\mathrm{dg}}-$ is the volume of dry flue gases, $\mathrm{Nm}^{3} / \mathrm{kg}$

To determine the combustion efficiency for both technologies, the main independent parameters are Net calorific value $\left(Q_{z}{ }^{d}\right)$ and ash content of the fuel (A). Both basically are defined by the wood type and the soil and environment conditions in which it has been grown. As seen in (1) and (3), the dependent variables are unburned $\mathrm{C}$ in the ashes and $\mathrm{CO}$ in the exiting flue gases.

Another important parameter for evaluation of the combustion process is char burnout (b) (6) [11, 12]. It represents the degree at which the fuel particles have been burned during the combustion process.

$$
b=\frac{1-\frac{A}{a s h_{1}}}{1-A}[11,12],
$$

where

$b$ - char burnout, $\%$

A - ash content of the fuel, $\%$

$\mathrm{ash}_{1}$-ash content of the collected char, \%

Parameters $\operatorname{ash}_{1}$ and $\mathrm{C}_{\mathrm{fa}}$ basically describe the same parameter - unburned amount of the fuel in the ash $\left(\mathrm{C}_{\mathrm{fa}}\right)$, but from a different perspective. The main combustion process indicators describing the state of complete combustion are the amount of unburned matter in the ash (1), (3) and (6), and the CO emissions (1), (3). Fuel parameter considered for the all three combustion calculations is the ash content (1), (3) and (6). The net calorific value which represents the amount of energy supplied with the fuel is an important fuel parameter.

In the next sections other fuel parameters influencing the combustion process and efficiency will be discussed. These are moisture content, wood dust particle size and shape, volatile matter. These four are discussed as fuel properties which have determining influence on $\mathrm{CO}$ emissions $\left(\mathrm{V}_{\mathrm{co}}\right)$ and the degree of complete char combustion $-\mathrm{C}_{\mathrm{fa}}$ and ashl.

\section{WOOD DUST PROPERTY IMPACT ON COMBUSTION}

The wood powder combustion process and flame stability is strongly dependent on fuel quality. Wood powder as a fuel is characterized by parameters specified in European standard CEN/TS 14961 "Solid biofuels - Fuel specifications and classes". The fuel properties are very important for small capacity boilers. The lower the capacity of the burner is, the higher the requirements for the fuel. The main parameters to which attention must be paid are moisture content and particle size, the particle shape influences the combustion process as well $[13,5]$.

The Proximate and ultimate analysis properties of the wood powder fuel used for suspension combustion are viewed in Table I. Proximate analysis includes moisture, ash (A) and volatile matter content of the fuel as well as net calorific value (Qzd). The ultimate analysis comprises carbon (C), hydrogen $(\mathrm{H})$, oxygen $(\mathrm{O})$, nitrogen $(\mathrm{N})$ and sulphur $(\mathrm{S})$ content. The wood dust particle size and the capacity of the burner in which the fuel was used are specified. As most of the applications include co-firing wood dust fuels in present fossil fuel combustion systems, Table I also includes dust specification used for those applications. 


\section{Moisture content}

The higher the moisture content of the fuel, the longer it takes for the particle to ignite AND COMBUST completely. In this case a larger amount of heat is used to dry the particle in the combustion chamber. This process postpones the ignition of the particle, thus the combustion starts further away from the burner. This can raise problems with the flame stability and additional damage made to the furnace walls. If the combustion is organized well, there will be no problems with the ignition of the suspension and the flame stability, but the volume of the combustion chamber is then required to be larger. In this case, the chamber length has to be longer to avoid contact of the flame with the furnace wall. If the fuel and air feed is not adjusted to the moisture content, the flame becomes unstable and larger scale of incomplete combustion can occur, resulting in lower efficiency (higher $\mathrm{CO}$ and unburned matter amounts).

As it can be seen in Table I for combustion of $100 \%$ wood dust blends, all samples have moisture content above $10.1 \%$. For co-combustion together with gas and straw, the moisture content can be up to $13 \%$. For large capacity applications like $315 \mathrm{MW}_{\text {fuel }}$ power stations, the moisture content for the pine sawdust co-combusted with coals can be up to 51-63\% on fuel as received basis [4].
As shown in Figure 1, during the combustion process when the outer layer has fully oxidised into ash, the centre of the fuel particle still can be unburned and wet.
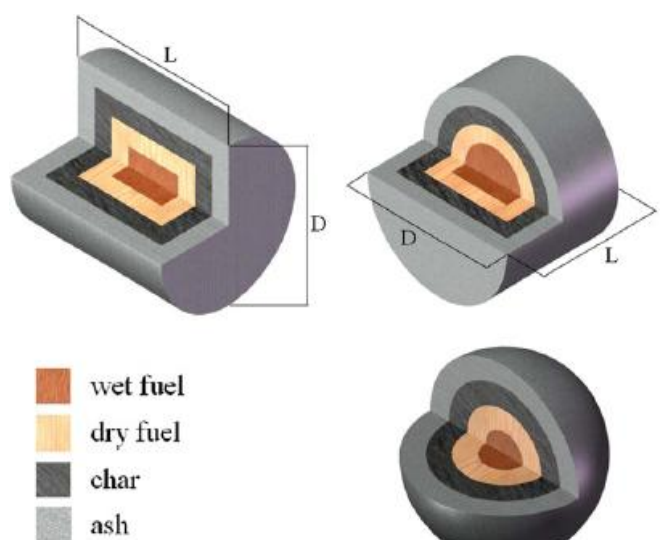

Fig. 1. Particle combustion stages [19]

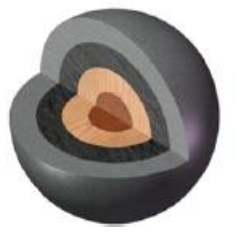

To avoid such a situation, higher temperatures and longer residence times are required for the moist particulates to combust and the outer layer is dried while the middle of the particle still remains with a certain amount of moisture. It is also an issue of heat transfer within the particle. If the particle

TABLE I

WOOD DUST PROPERTIES

\begin{tabular}{|c|c|c|c|c|c|c|c|c|c|}
\hline Fuel blend & & 100 & wood dust & & $\begin{array}{l}\text { Wood/coal - up } \\
\text { to } 30 / 70 \%\end{array}$ & $\begin{array}{l}\text { Wood/coal - } \\
\text { up to } \\
20 / 80 \%\end{array}$ & $\begin{array}{l}\text { Wood/gas } \\
(50 / 50 \%) ; \\
\text { Wood/straw } \\
(60 / 40 \%)\end{array}$ & $\begin{array}{l}\text { Wood/gas } \\
(20 / 80 \%)\end{array}$ & $\begin{array}{l}\text { Wood/coal - } \\
\text { up to } \\
30 / 70 \%\end{array}$ \\
\hline Power, kW & 108 & 150 & 204 & 400 & 20 & 50 & 175 & 500 & 2370 \\
\hline $\begin{array}{l}\text { Moisture, } \\
\text { \% AR }\end{array}$ & 7,5 & $4,3-10,1$ & 10 & $5,4-8,9$ & 9,04 & 6,8 & 13,60 & 7,3 & 3,4 \\
\hline Particle size & $<1,6 \mathrm{~mm}$ & $<1 \mathrm{~mm}$ & $<0,55 \mathrm{~mm}$ & $<0,5 \mathrm{~mm}$ & $<0,7 \mathrm{~mm}$ & $<0,25 \mathrm{~mm}$ & $<2 \mathrm{~mm}$ & $<1,4 \mathrm{~mm}$ & $<0,35 \mathrm{~mm}$ \\
\hline $\begin{array}{l}\text { Volatile } \\
\text { matter, \% } \\
\text { DM }\end{array}$ & 84,5 & $83,6-85,2$ & 87,60 & $81,0-83,3$ & 84,32 & 83,08 & 84,14 & 76,2 & 92,34 \\
\hline Ash, \% DM & 0,4 & $0,3-0,5$ & 0,42 & $0,3-0,5$ & 0,67 & 0,74 & 0,23 & 2,6 & 4,5 \\
\hline $\mathrm{C}, \% \mathrm{DM}$ & 49,80 & $49,8-50,4$ & 49,00 & $52,7-53,3$ & 49,53 & 49,96 & 53,80 & 46,90 & 48,6 \\
\hline H,\% DM & 6,2 & $6,0-6,2$ & 6,09 & $5,1-6,2$ & 6,33 & 6,56 & 7,93 & 5,2 & 4,65 \\
\hline $\mathbf{N}, \% \mathrm{DM}$ & $<0,1$ & $0,55-0,096$ & 0,57 & $0,1-0,2$ & 0,14 & 0,20 & 0,00 & 0,1 & 0,09 \\
\hline $\mathrm{S}, \% \mathrm{DM}$ & 0,01 & n. sp. & $<0,056$ & 0,01 & 0,01 & 0,06 & 0,00 & 0,04 & 0,093 \\
\hline O,\% DM & 43,7 & $42,8-43,9$ & 44,18 & $39,8-40,7$ & 43,33 & 42,23 & 38,04 & 37,8 & 42 \\
\hline $\mathrm{Q}_{\mathrm{z}}^{\mathrm{d}}, \mathbf{M J} / \mathbf{k g}$ & 17,7 & $19,0-19,3$ & 15,07 & $19,77-19,94$ & 16,44 & 16,62 & 16,68 & 17,07 & 16,54 \\
\hline Ref. & [14] & [13] & {$[15]$} & {$[5]$} & [16] & [17] & [12] & [18] & {$[1]$} \\
\hline
\end{tabular}

$\mathrm{AR}$ - as received

$\mathrm{DM}$ - dry matter

$\mathrm{Q}_{\mathrm{z}}^{\mathrm{d}}-$ Net calorific value

n. sp. - not specified 
is not fully combusted, it can be deposited on the bottom of the chamber and additional fouling can occur. The significance of the moisture content is linked with the particle size. The larger the particle, the higher moisture content can be accumulated within it.

As it is necessary to provide constant and steady fuel and air supply for the burner, additional attention must be paid to fuel feeding stability. If the suspended wood amount in the airfuel mixture is irregular, the flame can become unstable and even lead to the flame blow-off. High moisture content contributes to the fuel feeding, as very moist powder is more likely to form areas of agglutinated dust in the fuel storage bin i.e. bridging.

\section{Particle size}

One of the reasons of unstable feeding can be fuel bridging inside the storage container. Aside from moisture content, two additional fuel parameters are to be taken into account -particle size and shape. Particles of different shapes are most likely to bridge over the more even shaped. The precursors for bridging are elongated and narrow shaped particles, low bulk density of the wood powder fuel as well promotes the bridging. Particles of sizes $315 \mu \mathrm{m}$ and $800 \mu \mathrm{m}$ are the ones which tend to cause a bridging problem [20]. Finer particles tend to bridge due to electrostatic forces which become more apparent for fine particles $(<250 \mu \mathrm{m})$. During the fuel feeding inside the combustion chamber, finer particles tend to form build up on tube walls. When this build-up falls down, it combusts inside the combustion chamber as a larger particle, thus forming some peaks of $\mathrm{CO}$ emissions [13, 5]. For suspended wood combustion, fuel particles are milled to a range of $10 \mu \mathrm{m} 1000 \mu \mathrm{m}$ or more to ensure higher combustion efficiency and burnout [9]. For fluidized bed (FB) systems, the particle size requirement is not so high; particles of $2-5 \mathrm{~mm}$ can be burned [9]. FB and circular FB can be operated starting from $20 \mathrm{MW}_{\mathrm{th}}$. In some systems the particulate matter can be till $80 \mathrm{~mm}$, for CFB - up to $40 \mathrm{~mm}$. For pulverized fuels, the upper limit is $10-20 \mathrm{~mm}$ [8]. The particle size depends on the system and burner considered. The power capacity of the combustion systems as mentioned before plays a major role. For small capacity systems, the particle range is revealed in Table I.

As seen in the Table I, most of the fuel particles are finer than $1 \mathrm{~mm}$. For low capacity boilers, a finer powder is required. The particle size directly influences the flame structure. The finer the particles, the faster they ignite and combust. This fast ignition results in higher flame temperatures closer to the burner and lower flame temperatures at the end of the combustion chamber [13]. High flame temperatures mean higher $\mathrm{NO}_{\mathrm{x}}$ emissions and additional damage to the combustion chamber walls. The link between fine particles and higher $\mathrm{NO}_{\mathrm{x}}$ emission levels is proven by [13] due to a case study and result analysis using partial least squares (PLS) method. In the research results clearly demonstrate a link between the combustion of finer wood powder (containing large amount of particles in size of up to $350 \mu \mathrm{m})$ and flame temperature. The link is revealed by the elevated temperatures closer to the burner exit region and lower temperatures at end of the combustion chamber. The finer the particle, the less time it takes to ignite. For fine particles, the moisture evaporates faster and the release of volatile matter starts earlier $[14,5]$.

As well as the moisture content, the particle size influences the char burnout (6). For the limited volume combustion chamber, the temperatures must be higher and the mixing better, to ensure that the larger particles are completely oxidized into fly ash till the end of the combustion chamber is reached. If it is not, then the particle is deposited on the bottom of the chamber. This raises the necessity to stop the burner and clean the combustion chamber. This process is visualised with simulations in [13]. As it can be seen in fig. 1, the combustion of the particle occurs gradually. For the larger sized particles, the duration is longer than for the smaller ones. Mostly the particle size is determined by sieving through sieves with different aperture size. This analysis is approximate, as not completely the whole diameter and particle volume is taken into account. More precise is laser diffraction analysis, but it takes longer to analyse the sample [20]. High precision analysis is necessary when precise particle volume must be determined. Sieve analysis in this case is less precise as there is a possibility for a particle of smaller volume not to pass an aperture while a larger volume particle passes. This can happen due to the shape differences of the fuel. A spherical particle is more likely to pass the sieve eye than an elongated, cylindrical particle.

\section{Particle shape}

It is reported that particle shape influences the combustion time of the wood powder $[13,21]$. The parameter to describe the particle is shape factor, whereas the most important for this case is circularity and particle roughness. Circularity describes whether the particle shape is close to a perfect circle or it is elongated. The roughness shape factor describes the structure of the boundary line for the particle [20]. The main shape types for the pulverized wood particles are: quadratic (flakelike), cylindrical and spherical. The factors take into account how circular, narrow, elongated and rough the particles are. By single particle analysis in entrained flow reactor described in [21] it is determined that devolatilization of the particle is slower for near-spherical shaped particles. The most rapid gasification occurs for flake-like shaped particles as the particle specific volume is lower, but the reactive surface is larger through which the volatile matter can be released [21].

\section{Volatile matter}

Volatile matter of the fuel has a large influence on the combustion process. The volatile compounds account for the combustion in the gas phase i.e. the volatile oxidation. In Table I it can be seen that the average volatile matter of wood dust used for suspension burning is 76.2 - $92.34 \%$. The average volatile matter for the viewed case studies is $84 \%$ which is $\sim 3$ times more than that of pulverized coal (average $\sim 27 \%$ vol. matter) $[17,15,1]$. When the corresponding temperature has been reached, a rapid release of volatile compounds starts ensuring a very high burning rate of the wood dust when ignited [9]. 
Due to the high volatile content, the combustion zone is larger than for the fuels with low content of volatiles e.g. coal. Comparing the flames for both fuels, there is a larger amount of unburned gases ( $\mathrm{CO}$ and unburned hydrocarbons) in the area closer to the burner for wood dust. This happens due to increased release of volatile content, increasing the flame temperature closer to the burner region. Further back, the coarser particles continue to devolatilize and char of the fine particles is being oxidized [15, 22, 13]. For wood dust burners, it is necessary to organize the flame in order that volatiles are burned across the whole combustion zone. It is favorable to ensure that fine char particles are being oxidized completely having additional external heat source - oxidation of volatiles. To organize the flame to reach the highest combustion efficiency with lower emissions - it is necessary to pay additional attention to the fuel and combustion air feeding.

The average chemical composition of the wood dust fuels burned in the given applications as seen in Table I, complies with the values specified in CEN/TS 14961 for coniferous and deciduous wood fuels. It is well known that high $\mathrm{N}$ contents of the fuel contribute to high $\mathrm{NO}_{\mathrm{x}}$ emissions.

\section{INCREASING THE COMBUSTION EFFICIENCY}

As mentioned before - an important issue is the fuel and air feeding. One method on how to increase the combustion efficiency is pre-treatment of the fuel to reduce the moisture content, and the particle size. By choosing the mill type, different size reduction efficiencies and particle shapes can be acquired [20].

The basic principle of the burner operation is as follows: through a central tube a wood dust-air suspension is injected. To lower the emissions and increase the combustion efficiency, secondary and tertiary air is introduced through the outer tubes. The supply air is being staged. The method to increase the combustion efficiency without major changes in the combustion chamber dimensions is to adjust the burner to the fuel properties. The main factors describing the burner set up are the stoichiometric air ratio, air preheating temperature and the swirl number. The air ratio describes the fuel, fuel transport and combustion air feed rates. The air can be preheated to facilitate the ignition and combustion of wood dust. In this paper the supply air swirling is viewed in more detail.

\section{Swirl number}

One of the common techniques on how to stabilize the flame is by giving a swirling momentum to the staged air jets. Swirling secondary and tertiary air is introduced across the fuel flow giving it the swirling movement. Swirling momentum of the combustion air is achieved by movableblock swirl generators [23, 24].

The achieved swirling flame is more stable due to occurring re-circulation of hot combustion gases from back of the combustion chamber into the burner inlet. The heat of the combustion gases dries the incoming fuel particles [13].

Due to the swirling effect internal (IRZ) and external recirculation zones (ERZ) are formed, see fig. 2.
The internal recirculation zone is formed downstream of the burner quarl. In the fig. 2 it can be seen that fuel feeding air is intense enough to penetrate the IRZ. In the middle of the flame, a fuel-rich zone is being formed which ensures lower $\mathrm{NO}_{\mathrm{x}}$ emissions. In the IRZ the residence time of some fuel particles and volatile gases is prolonged ensuring a higher degree of complete combustion. As well the particles being penetrated through the zone are more intensively dried. ERZ is formed around the flame. The fuel-air mixture is fuel-lean. It is formed by a reverse flow of combustion mid-products induced by entrainment towards issuing jets.

In the external recirculation zone the complete combustion of the yet unburned products is facilitated. This occurs in conditions where the swirl number is high enough; for the viewed case it is 1.06 [15].

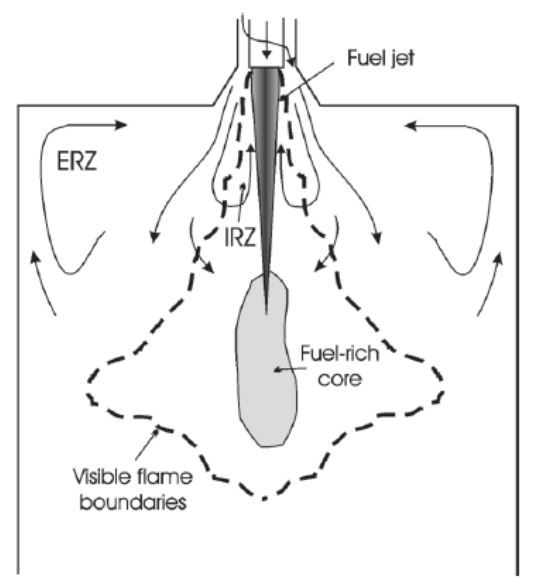

Fig. 2. Internal and external recirculation zones [15]

The swirl number is a quantitative parameter to estimate the degree (strength) of the swirl. The swirl number $(S)$ is calculated as (7)

$$
S=\frac{G_{\theta}}{G_{z} \frac{d}{2}}[25,23,24],
$$

where

$\mathrm{G}_{\theta}-$ axial flux of angular momentum, $\mathrm{m}^{3} / \mathrm{s}$

$\mathrm{G}_{\mathrm{z}}-$ axial flux of axial momentum, $\mathrm{m}^{2} / \mathrm{s}$

$\mathrm{d}$ - diameter of the exit nozzle, $\mathrm{m}$.

It is not likely to organize swirled fuel suspension flow through the central tube. Swirling is characteristic only to supplementary (staged) air streams, e.g. secondary and tertiary air. It can be adjusted by the angles of the swirl generator blades and air flow rate through separate air feeding units [13, $14,15,17,1,16]$. From (7) it can be understood that if in the larger angle the swirl generator blocs are placed and higher air feed is applied, the higher swirl number is reached. For different sets of swirl burners, the swirl number range can differ [23].

The swirl number can be used as a strong parameter to determine fuel and air feeding influence on the flame length. It is reported [5] that a longer flame can be achieved with increasing primary air flow with the swirling. A longer flame 
means longer residence time of the combustion products in the combustion chamber. It also can mean damage to the combustion chamber if the dimensions are not considered. Additionally, lower NOx emissions as the heat in the flame zone is more widely distributed thus less high temperature regions are being formed within it. By [14] it was found out that low $\mathrm{CO}$ emissions can be acquired by feeding primary and swirled secondary and tertiary air with equal feeding rates. To ensure higher combustion efficiency, it is necessary not only to stage the air feeding (secondary and tertiary air) but also to swirl the flame. This is done in order to stabilize the flame and ensure faster drying and more complete combustion of the fuel.

To successfully burn the fuel and reach higher combustion efficiency, it is necessary to pre-treat it physically. The raw wood fuel should be pulverized and dried prior to igniting which makes it possible to achieve fast ignition and burning rates [26]. It is determined that impact mills are more efficient producing more fine particles rather than knife mills [13]. For coal co-combustion applications it is common to introduce the wood fuel together with coal into the coal pulveriser mills [27].

For $100 \%$ wood dust fuel combustion in suspension burners, natural gas is commonly used as a start up fuel. In Japan [5] prior to combustion of wood dust/air suspension in $4.7 \mathrm{~m}^{3}$ large combustion chamber it was preheated till $800{ }^{\circ} \mathrm{C}$. Natural gas was also used to preheat the secondary and tertiary combustion air jets to $300{ }^{\circ} \mathrm{C}$ [5]. For experiments of [15] the secondary air was preheated to $270{ }^{\circ} \mathrm{C}$. In Sweden [13] the burner at first was operated solely on natural gas for approximately 5 minutes prior to switching to pulverized wood fuel (combustion chamber size $-0.64 \mathrm{~m}^{3}$ ).

In regard to wood dust combustion, it is necessary to take into account additional issues with ash formation. During the wood dust combustion larger amount of ash is being deposited on heater tubes due to higher content of $\mathrm{Cl}, \mathrm{K}$ and $\mathrm{Na}$ than of coal and natural gas. Additionally the lower ash melting temperature results in aggravating and fouling problems on the combustion chamber walls and heater tubes [27, 22]. Research [17] shows that by adding biomass for co-combustion with coal decreases the deposition forming rate even at higher temperatures. The formed deposits are loose and easy to remove. This probably is due to the low capacity application where lower temperatures are reached.

\section{CONCLUSIONS AND DISCUSSION}

Combustion process and combustion efficiency have been reviewed for low capacity wood dust combustion applications. It can be concluded that the two main parameters determining the combustion efficiency are $\mathrm{CO}$ emissions and unburned carbon in the fly and deposited ash. Both of the parameters are dependent on flame stability and area of the formed combustion zone. The main wood dust properties and their influence on the combustion efficiency have been discussed. The properties are moisture content, particle size and shape as well as content of volatiles.
In order to ensure higher combustion efficiency the main wood dust quality boundary conditions for small scale suspended wood combustions can be derived:

- Moisture content of $10 \%$ must not be exceeded in order to efficiently combust $100 \%$ wood dust fuel blends.

- Particles of the wood dust blend should be smaller than $1 \mathrm{~mm}$. Attention must be paid to the average diameter of the blend.

- The wood dust particles should be of flake-like and narrow shape.

- The volatile matter content for the wood dust should be $80 \%$ or higher.

The boundary conditions on moisture and particle size of the wood dust blend corresponds with information given by World Trade Service AB Powder Burners.

This paper serves as a basis for development and improvement of the wood dust combustion technologies for heating production at the Riga Technical University. Further research and work will be dedicated to the development of the burner model and an experimental stand.

The findings can also be used by international scientists dealing with suspended biomass dust combustion in powder burners. The knowledge can be used for an economic evaluation of fine particle biomass use in present fossil fuel combustion applications in regard to the availability of quality requirements.

\section{ACKNOWLEDGEMENTS}

This work has been supported by the European Social Fund within the project «Support for the implementation of doctoral studies at Riga Technical University».

\section{REFERENCES}

1. Molcan, P., Lu, G., Bris, T. et. al. Characterization of biomass and coal co-firing on a 33 MWth Combustion Test Facility using flame imaging and gas/ash sampling techniques. Fuel, 2009, vol. 88, p. 2328-2334.

2. Sarenbo, S. Wood ash dilemma-reduced quality due to poor combustion performance. Biomass \& Bioenergy, 2009, vol. 33, 1212-1220.

3. Skrifvars, B-J., Lauren, T., Hupa, M. et. al. Ash behaviour in a pulverized wood fired boiler-a case study. Fuel, 2004, vol. 83, p. 13711379.

4. Sovalainen, K. Co-firing of biomass in coal-fired utility boilers. Applied Energy, 2003, vol. 74, p. 369-381.

5. Nishiyama, A., Shimojima, H., Ishikawa, A., et. al. Fuel and emissions properties of Stirling engine operated with wood powder. Fuel 2007, vol. 86, p. 2333-2342.

6. Standard CEN/TS 14961 Solid biofuels - Fuel specifications and classes

7. Bioenergijas tehnologijas, D. Blumberga, I Veidenbergs, F Romagnoli, C. Rochas, A. Žandeckis, Riga: Institute of energy Systems and Environment, 2011

8. Handbook of Biomass combustion \& Co-firing, S. van Loo, J. Koppejan, UK : Earthscan, 2008

9. Williams, A., Jones J.M., Ma, L., et. al. Pollutants from the combustion of solid biomass fuels. Progress in Energy and Combustion Science, 2012, vol 381 113-137.

10. Janvijitsakul, K., Kuprianov, V. I. Major gaseous and PAH emissions form a fluidized-bed combustor firing rice husk with high combustion efficiency. Fuel processing technology, 2008, vol. 89, p 777-787

11. Weber, R., Kupka, T., Zajac, K. Jet flames of refuse derived fuel. Combustion and Flame, 2009, vol 156, p. 922-927 
12. Casaca, C., Costa, M. Co-combustion of biomass in a natural gas-fired furnace. Combustion Science and Technology, 2010, vol 175, N 11, p. 1953-1977.

13. Paulrud, S., Nillson, C. The effects of particle characteristics on emission from burning wood fuel powder. Fuel, 2004, vol. 83, p. 813821.

14. Eriksson, G., Kjellström, B., Lundqvist, B. et. al. Combustion of wood hydrolysis residue in a $150 \mathrm{~kW}$ powder burner. Fuel, 2004, vol. 83, p. 1635-1641.

15. Ballester, J., Barroso, J., Cerecedo L. M. et. al. Comparative study of semi-industrial-scale flames of pulverized coals and biomass. Combustion and Flame, 2005, vol. 141, p. 204-215.

16. Lin, W., Jensen., P. A., Jensen, A. D. Biomass Suspension Combustion: Effect of Two-Stage Combustion on $\mathrm{NO}_{\mathrm{x}}$ Emissions in a LaboratoryScale Swirl Burner. Energy \& Fuels, 2009, vol. 23, p. 1398-1405.

17. Kupka, T., Mancini, M., Irmer, M., Weber, R. Investigation of ash deposit formation during co-firing of coal with sewage sludge, saw-dust and refuse derived fuel. Fuel, 2008, vol. 87, p. 2824-2837.

18. T., Costen, P., Kandamby, N. H. et. al. The influence of burner injection mode on pulverized coal and biosolid co-fired flames. Combustion and Flame, 1994, vol. 99, p. 617-625.

19. Mehrabian, R., Zahirovic, S., Scharler, R. et. al. A CFD model for thermal conversion of thermally thick biomass particles. Fuel Processing Technology, 2012, vol. 95, p. 96-108.

20. Paulrud, S., Mattsson, J. E., Nilsson C. Particle and handling characteristics of wood fuel powder: effects of different mills. Fuel processing technology, 2002, vol. 76, p. 23-29.

21. Hong, L., Ip, E., Scott, J. et. al. Effects of particle shape and size on devolatilization of biomass particle. Fuel, 2010, vol. 89, 1156-1168.

22. Demibras, A. Combustion characteristics of different biomass fuels. Progress in Energy and Combustion Science, 2004, vol. 30, p. 219-230.

23. Palm, R., Grundmann, S., Weismüller, M. et. al. Experimental characterization and modelling of inflow conditions for a gas turbine swirl combustor. International Journal of Heat and Fluid Flow, 2006, vol. 27 , p. 924-936.
24. Syred N., A review of oscillation mechanisms and the role of the precessing vortex core (PVC) in swirl combustion systems. Progress in Energy and Combustion Science, 2006, vol. 32, p. 93-161.

25. Khanna V. K. A Study of the Dynamics of Laminar and Turbulent Fully and Partially Premixed Flames, PHD thesis, Virginia Polytechnic Institute and State University, 2001, p. 239.

26. Spliethoff, H., Power generation from Solid Fuels. Berlin, Heidelberg: Springer Berlin Heidelberg, 2010, p. 672

27. Sami, M., Annamalai, K., Wooldridge, M. Co-firing of coal and biomass fuel blends. Progress in Energy and Combustion Science, 2001, vol. 27 , p. 171-214.

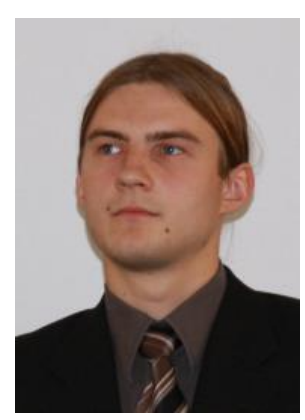

Kaspars Silins, M. sc., scientific assistant, Riga Technical University, Institute of Energy Systems and Environment. In 2009 Kaspars Siliņš acquired Bachelors degree in Environmental Engineering at Riga Technical University. Bachelor's thesis "Determination of solid particle concentration at coal transhipment site". In year 2010 he acquired Masters Degree in Environmental Engineering at Riga Technical University, faculty of Energy and Electronics. Master's thesis "Reduction of nitrogen oxides in small capacity biomass boilers". In year 2011 Kaspars Siliņš has started his PHD studies in Environmental Engineering at RTU.

Since year 2008 Kaspars Siliņš has been working as a laboratory assistant and since 2010 as scientific assistant at Institute of Energy Systems and Environment. Kaspars Silin̦š is an author of 7 scientific publications, has participated in 7 scientific research projects. The main research areas are renewable energy resources, combustion systems and emissions.

Address: Kronvalda boulevard 1, LV-1010, Riga, Latvia

Phone: +371 67089908

E-mail: kaspars.silins@rtu.lv 